\title{
Enhancement of Biogas Production from Fixed Dome Biogas Plant through Recycling of Digested Slurry
}

\author{
Hamza Baloch ${ }^{1}$, Barkatullah Kandhro', Azizullah Channa ${ }^{1}$, Sheeraz Ahmed Memon ${ }^{1 *}$, Muhammad Yousuf Jat \\ Baloch $^{1,2}$ and Abdul Aziz Chan ${ }^{1}$ \\ ${ }^{1}$ Institute of Environmental Engineering and Management, Mehran University of Engineering \& Technology, Pakistan \\ ${ }^{2}$ College of New Energy and Environment, Jilin University, China
}

Submission: February 01, 2022; Published: February 23, 2022

*Corresponding author: Sheeraz Ahmed Memon, Institute of Environmental Engineering and Management, Mehran University of Engineering \& Technology, Jamshoro, Sindh, Pakistan

\begin{abstract}
The aim of this study was to assess the maximum biogas production through optimizing the fixed dome biogas plant at different conditions installed at Hyderabad district. The biogas plant was operated on fresh animal dung to water (1:1) ratio and fresh dung slurry to digested slurry ratio of 3:1 and 1:1 as to measure the maximum production of biogas. The biogas production was measured by using drum type wet gas flow meter with model number TG05/3, having minimum flow rate $1 \mathrm{~L} / \mathrm{h}$ and maximum flow rate of $60 \mathrm{~L} / \mathrm{h}$. The gas composition was measured on Gas Chromatography (GC) with thermal conductivity detector at $150 \stackrel{\circ}{\circ}$. The biogas production was achieved to $0.432 / \mathrm{kg}$.VS with $64 \%$ of $\mathrm{CH}_{4}$ on $1: 1$ ratio and VS reduction was $23 \%$. Then, the maximum biogas production was achieved to $0.98519 \mathrm{~m} 3 / \mathrm{kg}$.VS with $\mathrm{CH}_{4}$ content of $68 \%$ and VS reduction of $39 \%$ when $50 \%$ of digested slurry was recycled back into the digestion. Therefore, the results of this study indicated that the recycling of the digested slurry with the mixture of cow dung were beneficent and helping in overcoming the problem of biogas plants in cold seasons which will maintain higher gas production and will conserve water.
\end{abstract}

Keywords: Animal dung; Maximum; Biogas production; Slurry recycling; Cold season

Highlights

a) Biogas plant installed at the right bank of the Indus River, Hyderabad, Sindh, Pakistan

b) Biogas plant assessed on different ratios and temperature inside the digester.

c) Digester performance was assessed by measuring gas production, VS reduction, and $\mathrm{CH}_{4}$ content.

d) Highest biogas production, VS reduction, and $\mathrm{CH}_{4}$ content achieved when digester operated at stage-III.

e) Recycling of digested slurry with feed slurry is beneficent and helping in overcoming the problems of biogas plants for lower biogas production in cold seasons.

\section{Introduction}

Recently the use of fossil fuels has led to serious threat to society by increasing environmental pollutions. Therefore, the tendency for renewable energy sources is increasing day by day and many studies have been carried out on utilization of different renewable energy sources to overcome the pollution caused from usage of fossil fuels [1]. The 'Reduce', 'Reuse' and 'Recycle' ('3 R's') referred to reduce the amount of waste to product, considered the best ways for the green environment, many organic wastes such as banana peels, orange, sapodilla peels help to treatment of wastewater, and low-cost adsorption techniques to remove arsenic from groundwater [2-6]. Biomass is one such resource that could play a substantial role in a more diverse and sustainable energy. The energy obtained from biomass is a form of renewable energy and, in principle, utilizing this energy does not add carbon dioxide, a major greenhouse gas, to the atmosphere, in contrast to fossil fuels [7]. Animal dung is a potentially large biomass resource and dried dung has the same energy content as wood when burned for heat, the efficiency is only about $10 \%$. About 150 million tones (dry) of cow dung are used as fuel each year across the globe. The efficiency of conversion of animal residues could be offer multiple benefits. For cooking and other household thermal task, it is simple and reasonably efficient to use the gas directly in conventional low-pressure gas burners. The digester effluent adds economic value by providing valuable fertilizer. It leads to environmental protection as well as improving sanitary conditions in rural area. Biogas plants are widely in operation in China, India, Sudan, Taiwan, etc. [8,9]. 
Anaerobic digestion (AD) is one of the processes by which energy may be obtained from biomass [6,10]. AD involves disintegration of carbon-based material in molecular free oxygen $\left(\mathrm{O}_{2}\right)$ atmosphere. It results information of methane $\left(\mathrm{CH}_{4}\right)$, Carbon dioxide $\left(\mathrm{CO}_{2}\right)$, Ammonia $\left(\mathrm{NH}_{3}\right)$ and other low molecular weight trace gases and carbon-based acids [11]. The basic metabolic pathway of anaerobic digestion is Hydrolysis, Acidogenesis,
Acetogenesis, and Methanogenesis as shown in Figure 1. Biogas is the type of combustible gas which consists of methane and carbon dioxide. Formation of $\mathrm{CH}_{4}$ through AD (bio-methane) is a clean and renewable source of energy. It can substitute fossil fuels and can decrease environmental pollution including acid rains and global warming [12]. The Biogas and digested slurry are the important products of anaerobic digestion process.

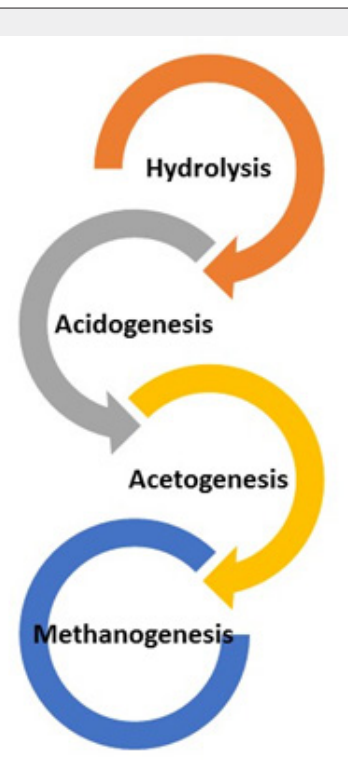

Complex organic matter

Carbohydrates, proteins, fats

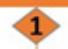

Soluble organic molecules

Sugars, amino acids, fatty acids

Volatile fatty acids

3

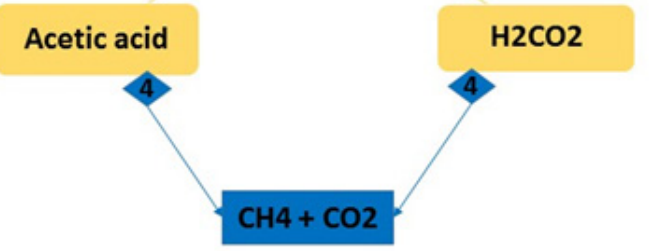

Figure 1: Process stages of anaerobic digestion process.

The digested slurry contains $93 \%$ of water $\left(\mathrm{H}_{2} \mathrm{O}\right), 7 \%$ of dry matter, $4.5 \%$ is organic matter and $2.5 \%$ inorganic matter [13]. The slurry of biogas contains different minerals like phosphorus, potassium, zinc, iron, manganese and copper. Since the microbes washed away are reintroduced back into the reactor, thereby providing additional microbial population [14]. The biogas production rate in fixed dome biogas plants is lower at the temperature range of $15-25^{\circ} \mathrm{C}$ and less reduction of volatile solids because there is no mixing mechanism in these types of plants to enhance biogas production [15].

However, there are many drawbacks of using anaerobic digestion for biogas production including slow degradation of biomass, slow development of anaerobic microbial colonies, poor process stability, low biogas production and long digestion period in cold seasons [16]. Furthermore, to enhance the biogas production from anaerobic digestion different methods have been investigated such as pre-treatment, co-digestion, utilization of advance digesters, innovative substrates, advancement in operational conditions (e.g., pH, temperature, hydraulic retention time, organic loading rate) and additives. These additives have shown improved biogas production yield, and many studies have been carried out using additives to anaerobic digestion system including enzymes, salts, metal oxides [17]. The recycling of the digested slurry has also been tried out to conserve water and to enhance biogas production [18]. The recycling of digested slurry is utilized as additive to the anaerobic digestion for enhancement of the biogas production yield. The digested slurry contains the methanogens bacteria population when it will be reintroduced into the reactor, it will enhance the production and composition of biogas.

To date, most of the research studies are conducted on enhancement of biogas production at laboratory scale and no one has conducted a full-scale assessment for enhancement of biogas production. To address this research gap, the aim of this study was to assess the maximum biogas production by optimizing the fixed dome biogas plant at different conditions including fresh dung to water ratio and digested slurry to fresh dung slurry ratio.

\section{Material and Methods}

\section{Study area}

The performance of biogas plants is dependent on local conditions in terms of climate, soil conditions, and substrate. The site selection for installation of biogas plant was selected based on the various parameters including unavailability of natural gas supply, availability of water, sunlight, and frequent availability of animal manure. The biogas plant was installed at Misri Shaikh Village Taluka Qasimabad, Hyderabad, Sindh, Pakistan and having 
coordinated Latitude $25^{\circ} 24^{\prime} 42.60^{\prime \prime} \mathrm{N}$ and longitude $68^{\circ} 19^{\prime} 7.41^{\prime \prime} \mathrm{E}$ as shown in Figure 2. This village is near highway Hyderabad on the right bank of the Indus River and surrounded by agriculture crops. This biogas plant was installed for 7 to 10 family members in a house to satisfy their cooking, heating, and lighting needs.

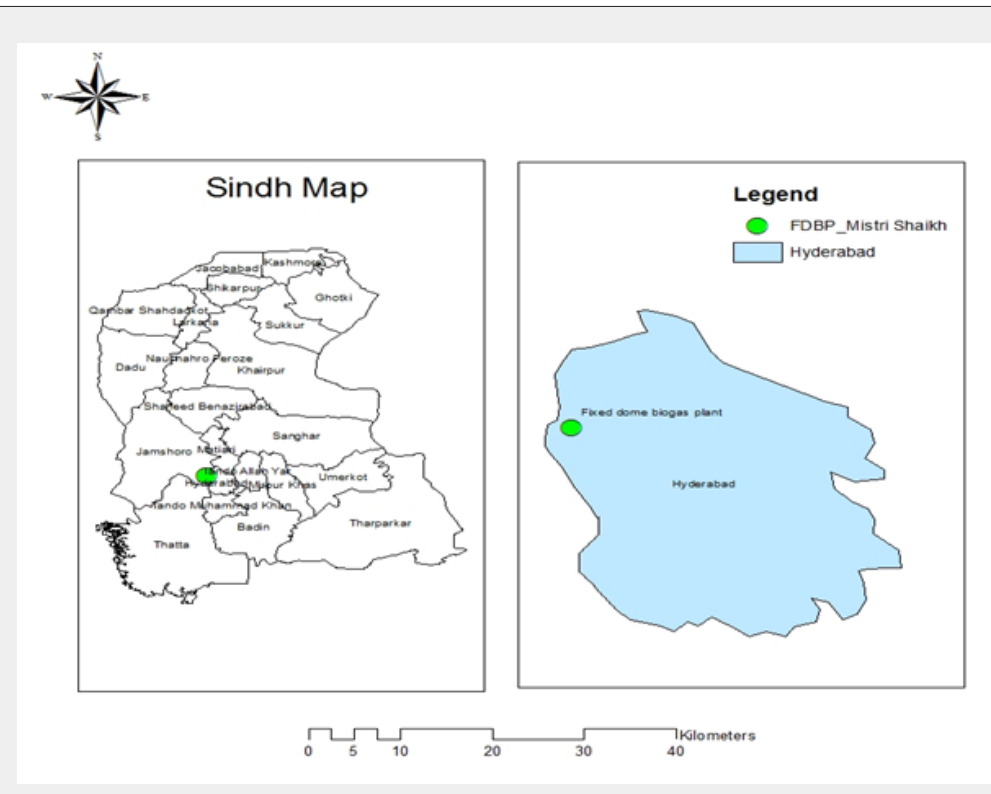

Figure 2: Site of biogas plant installation at Misri Shaikh Village, Qasimabad Hyderabad.

\section{Biogas plant startup}

Initially the biogas plant was charged with $75 \%$ of volume at $6-9 \%$ of TS concentration. After stabilization of dung slurry it was found that HRT of digester was 35 days. The fixed dome biogas plant was operated at three stages by using fresh animal manure, water and digested slurry. In stage-I, the biogas plant was operated on dung to water (D:W) at 1:1 ratio for 6 weeks. For that $40 \mathrm{~kg}$ of animal dung was collected from cattle farm and 40 liters of raw water was added in feeding tank and homogeneously mixed with agitator. After that the biogas plant was operated for another 6 weeks at fresh dung slurry to digested slurry at 3:1 during stageII and 1:1 ratio in stage-III. During second stage $25 \%$ of digested slurry into the feed slurry was mixed. Whereas, in stage-III it was operated by recycling $50 \%$ of digested slurry into the feeding tank with feed slurry. Table 1 shows the operating conditions of fixed dome biogas plant.

Table 1: Operating conditions of fixed dome biogas plant.

\begin{tabular}{|c|c|c|c|}
\hline Stages & Duration & Feeding Source & Description \\
\hline I & 6 & Animal Dung and Water (1:1) ratio & $\begin{array}{c}\text { Animal Dung + Water } \\
(50 \%+50 \%)\end{array}$ \\
\hline II & 3 & Fresh Dung Slurry and Digested Slurry (3:1) ratio & $\begin{array}{l}\text { Fresh Dung Slurry + Digested Slurry } \\
\qquad(75 \%+25 \%)\end{array}$ \\
\hline II & 3 & Fresh Dung Slurry and Digested Slurry (1:1) ratio & $\begin{array}{c}\text { Fresh Dung Slurry + Digested Slurry } \\
(50 \%+50 \%)\end{array}$ \\
\hline
\end{tabular}

\section{Analytical parameters}

The samples were collected from influent and effluent tank of fixed dome biogas plant installed in Misri Shaikh Village Qasimabad. The samples were analyzed for $\mathrm{pH}$, Total Alkalinity (TA), Volatile fatty acids (VFA), Total Solids (TS), and Volatile Solids (VS) at (APHA standard methods, 1998) in the Institute of Environmental Engineering and Management, Mehran University of Engineering \& Technology, Jamshoro, Sindh, Pakistan. The pH was measured with pH meter (Model HI 8424, Hanna). The TA and
V FAs were measured by titrimetric and distillation method. TS and VS were measured by gravimetric method using electric dry oven and electric muffle furnace. The analytical parameters and methods are shown in (Table 2).

\section{Estimation of biogas production}

The volume of biogas produced from digester was recorded weekly and each experiment was performed twice in a week. The volume of biogas was measured by using drum type gas 
meter (Ritter TG-05) that contains the pressure scale and the thermometer. According to calibration certificate the accuracy of drum type gas meter by using air as the calibration gas was $+0.16 \%$. The residential, commercial, and industrial buildings were used gas meters that consume fuel gas provided by gas utility. A pressurized amount of the gas flowing through the meter was measured by gas meters. The pictorial view shows the drum type gas meter (Ritter TG-05) used for biogas measurement as shown in Figure 3 available at Solid waste management laboratory of Institute of Environmental Engineering and Management, Mehran University of Engineering \& Technology, Jamshoro, Sindh, Pakistan Jamshoro. The gas was drawn from dome of biogas plant to the inlet of the drum gas meter, then gas flow of gas measured continuously.

Table 2: Analytical Parameters of feed slurry and effluent slurry.

\begin{tabular}{|c|c|c|}
\hline S\#. & Parameters & Method \\
\hline 1 & $\mathrm{pH}$ & pH Meter (HANNA HI 8424) \\
\hline 2 & $\mathrm{~T}(\stackrel{\circ}{\mathrm{o}})$ & Temperature Meter (HTC-2) \\
\hline 3 & $\mathrm{TA}(\mathrm{mg} / \mathrm{L})$ & Titrimetric Method \\
\hline 4 & VFAs $(\mathrm{mg} / \mathrm{L})$ & Distillation Method \\
\hline 5 & $\mathrm{TS}(\%)$ & Gravimetric Method \\
\hline 6 & VS $(\%)$ & Gravimetric Method \\
\hline
\end{tabular}

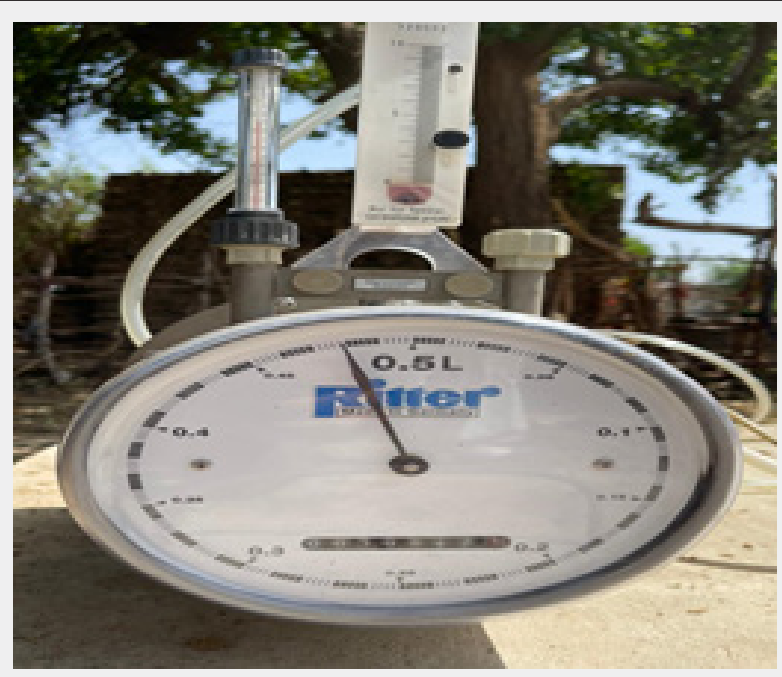

Figure 3: The pictorial view of drum type gas meter (Ritter TG-05) used for biogas measurement.

\section{Gas chromatograph}

Biogas composition was analyzed on Shimadzu Gas Chromatograph in order to know the $\mathrm{CO}_{2} \%$ and $\mathrm{CH}_{4} \%$ in the artificial Biogas composition. Biogas sample was injected through gas sampler on GC and run time was set for 3 minutes. After processing time, area of carbon dioxide gas peak and methane gas peak were calculated and converted into percentages. The methane was observed $79 \%$ and carbon dioxide was $16 \%$. The temperature for the experiments was calculated through temperature meter and atmospheric pressure was taken into account for biogas analysis, the initial GC analysis of gas sample as shown in Figure 4.

\section{Results and Discussion}

\section{Characterization of dung slurry}

The feed slurry and effluent slurry samples were taken from the fixed dome biogas plant. The $\mathrm{pH}$, TS (Total Solids), VS (Volatile Solids), VFA (Volatile Fatty Acids), and ammonia nitrogen were analyzed for feed and effluent slurry samples. The factors affecting biogas production by anaerobic digestion include $\mathrm{pH}, \mathrm{TS}, \mathrm{VS}, \mathrm{VFA}$, Alkalinity and Ammonia. The feed and effluent slurry pH was measured to $7.27 \pm 0.18$ (12) and $7.18 \pm 0.12$ (12) respectively as shown in Table 3 . The changes in $\mathrm{pH}$ were measured weekly of feed slurry and effluent slurry. The $\mathrm{pH}$ is one of the most important parameters for the stability of anaerobic digestion system that could affect the activity of acidogenic and methanogenic microorganisms $[16,19,20]$.

Whereas the alkalinity of feed slurry and effluent was achieved to $1786.429 \pm 507.21$ (12) and $2872.85 \pm 172.6$ (12) respectively. The average VFA/Alkalinity ratio was calculated to 0.7 . Volatile fatty acids are significant intermediates for bio methane production. VFAs are produced during acidogenesis and consumed during methanogenesis in anaerobic digestion. 
The rate of VFA production plays a significant role in maintaining process stability. VFAs are recommended to be considered as a critical parameter for operating anaerobic digesters. When the ratio of VFA to TA is 0.5 then $\mathrm{AD}$ system is reliable, but if the ratio exceeds the limit of 0.5 it considered the indication of instability of digester [21,22]. Furthermore, the TS and VS of feed slurry and effluent slurry were also analyzed to measure the solid content in digestion process. The TS content in feed slurry was found to $6.58 \pm 1.89(12)$ and in effluent slurry it was $3.82 \pm 1.58(12)$.

Table 3: Characteristics of feed slurry and effluent slurry.

\begin{tabular}{|c|c|c|c|}
\hline S\#. & Parameters & Feed Slurry & Effluent Slurry \\
\hline 1 & $\mathrm{pH}$ & $7.27 \pm 0.18(12)$ & $7.18 \pm 0.12(12)$ \\
\hline 2 & $\mathrm{TS}(\%)$ & $6.58 \pm 1.89(12)$ & $3.82 \pm 1.58(12)$ \\
\hline 3 & VS (\%) & $78.5 \pm 8.72(12)$ & $73.18 \pm 7.81(12)$ \\
\hline 4 & VFA (mg/L) & $1782.9 \pm 258.7(12)$ & $2872.85 \pm 172.6(12)$ \\
\hline 5 & Alkalinity $(\mathrm{mg} / \mathrm{L})$ & $190 \pm 12(6)$ & $380 \pm 30(6)$ \\
\hline
\end{tabular}

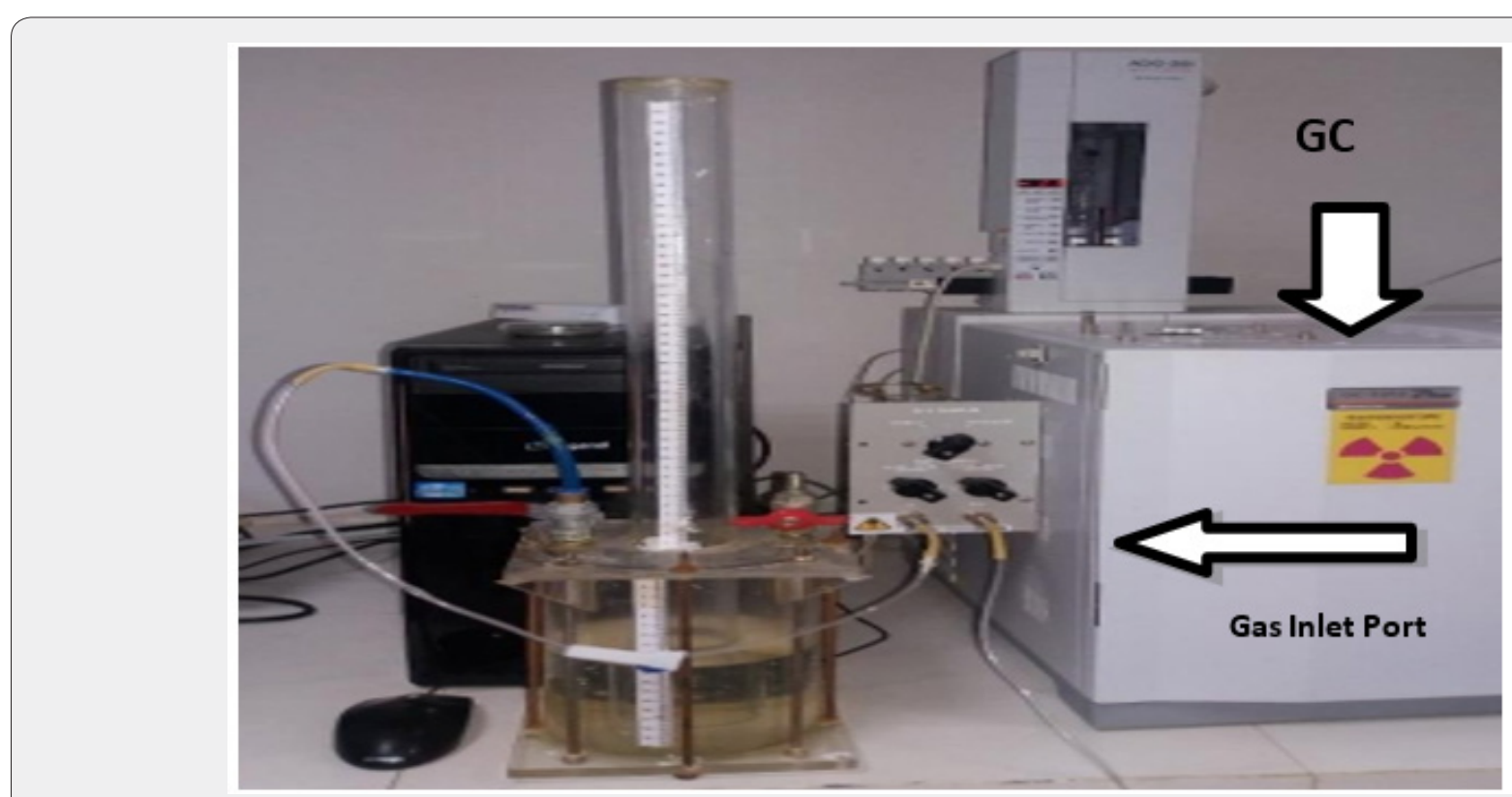

Figure 4: Gas chromatography for analysis of biogas composition.

\section{Feed and effluent slurry pH}

$\mathrm{pH}$ is one of the most important parameters for the stability of AD system, which could affect the activity of acidogenic and methanogenic microorganisms [23]. As the methanogenesis process started and methane generation was achieved. The feed slurry $\mathrm{pH}$ was monitored during all stages and it was in the range of 7-7.3. The effluent slurry $\mathrm{pH}$ of digester was recorded during all three stages and during stage-I the maximum $\mathrm{pH}$ was recorded to 7.41 in effluent slurry. Whereas, in stage-II the pH of effluent slurry was recorded to 7.4. The highest $\mathrm{pH}$ of effluent slurry was observed 7.6 during stage-III as shown in Figure 5. The appropriate $\mathrm{pH}$ of anaerobic digestion for the growth of methanogens is considered to be around 7.5 and $\mathrm{pH}$ in the reaction system reached more than 6 was considered appropriate for the methanogenesis process [24].

\section{Feed and effluent alkalinity}

The alkalinity was measured for feed slurry and effluent slurry during all three stages. The feed slurry alkalinity was achieved in the range of $1400 \mathrm{mg} / \mathrm{L}$ to $2600 \mathrm{mg} / \mathrm{L}$ during stage-I to stage-III. Whereas, the effluent slurry alkalinity was measured in the range of $2650 \mathrm{mg} / \mathrm{L}$ to $2880 \mathrm{mg} / \mathrm{L}$ during stage-I. The effluent alkalinity in stage-II and stage-III were noted in the range of 3050$3150 \mathrm{mg} / \mathrm{L}$ and $3180-3250 \mathrm{mg} / \mathrm{L}$ respectively. Figure 6 shows the alkalinities of feed and effluent slurry. The results of this study indicates that the alkalinity was increasing in stage-III as slurry was recycled back into the digester. The role of alkalinity is to avoid the $\mathrm{pH}$ variation, which decreases due to accumulation of VFA and increase because of the accumulation of the ammonia [25]. The alkalinity range of $2650-3250 \mathrm{mg} / \mathrm{L}$ indicates the process of digestion is stable. 


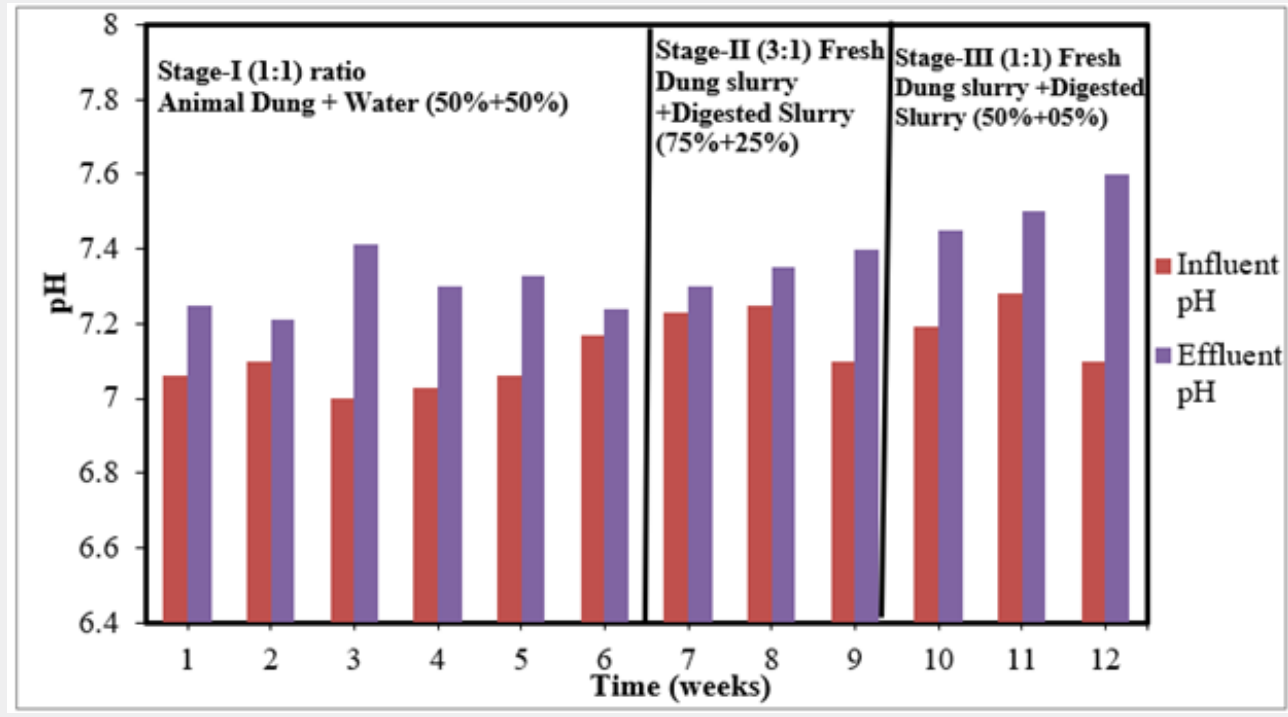

Figure 5: Feed and Effluent Slurry $\mathrm{pH}$.

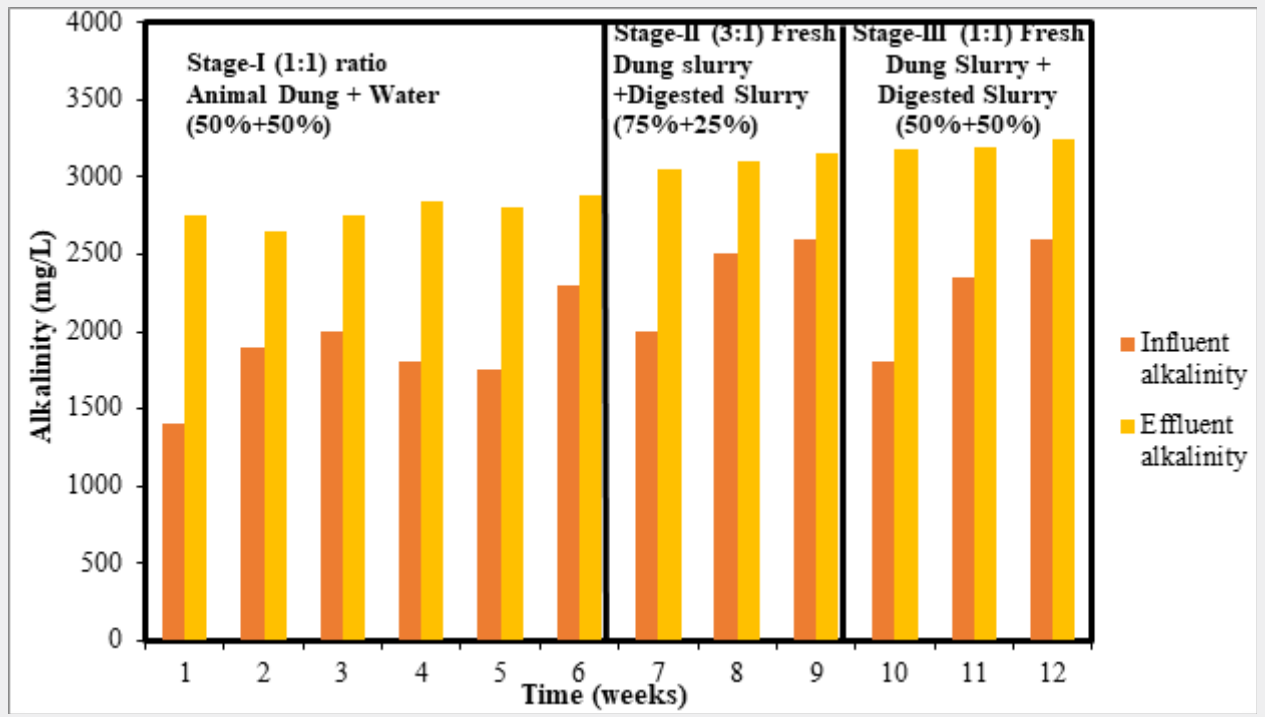

Figure 6: Influent and Effluent Alkalinity.

\section{Influent and effluent VFA}

In digestion process, the $\mathrm{pH}$, alkalinity and VFA are the main parameters for determination of inhibition [26]. The current work investigates the effect of VFA on anaerobic digestion process, i.e., hydrolysis, acidogenesis, and biogas production (methanogenesis). The methanogenic phase is normally considered the limiting step of the process due to the slow growth rate of the methanogenic bacteria. Various physical-chemical conditions effect the production of methane, and inhibition of bacterial activity by either substrate or product may be expected when their concentration is increased to extremes. For example, high VFA concentration in the system causes the inhibition of methanogenesis. Initially, the feed slurry sample of cow dung VFA was observed in between $720-1320 \mathrm{mg} / \mathrm{L}$. As the methanogenesis process started and methane generation was achieved the VFA was decreased from 1400-720mg/L as shown in Figure 7.

\section{Effect of slurry recycling on biogas production}

The biogas production was observed before digested slurry and after digested slurry. Initially the fixed dome biogas plant was operated in original condition with fresh cow dung to water (M:W) (1:1) ratio for six weeks. The maximum biogas production at original condition was observed $0.4325 \mathrm{~m}^{3} / \mathrm{kg}$.VS during stage-I. After 6 weeks the fixed dome biogas plant was operated with $25 \%$ 
of digested slurry and mixed with fresh dung slurry. The maximum biogas production was observed $0.5386 \mathrm{~m}^{3} / \mathrm{kg}$.VS during stageII. Furthermore, the fixed dome biogas plant was operated with $50 \%$ of digested slurry and $50 \%$ of feed slurry in stage-III and the maximum biogas production was obtained to $0.985198 \mathrm{~m}^{3} / \mathrm{kg} . \mathrm{VS}$ as shown in Figure 8. The results of present study demonstrated that the highest biogas production was achieved when digested slurry was recycled back into the digester.

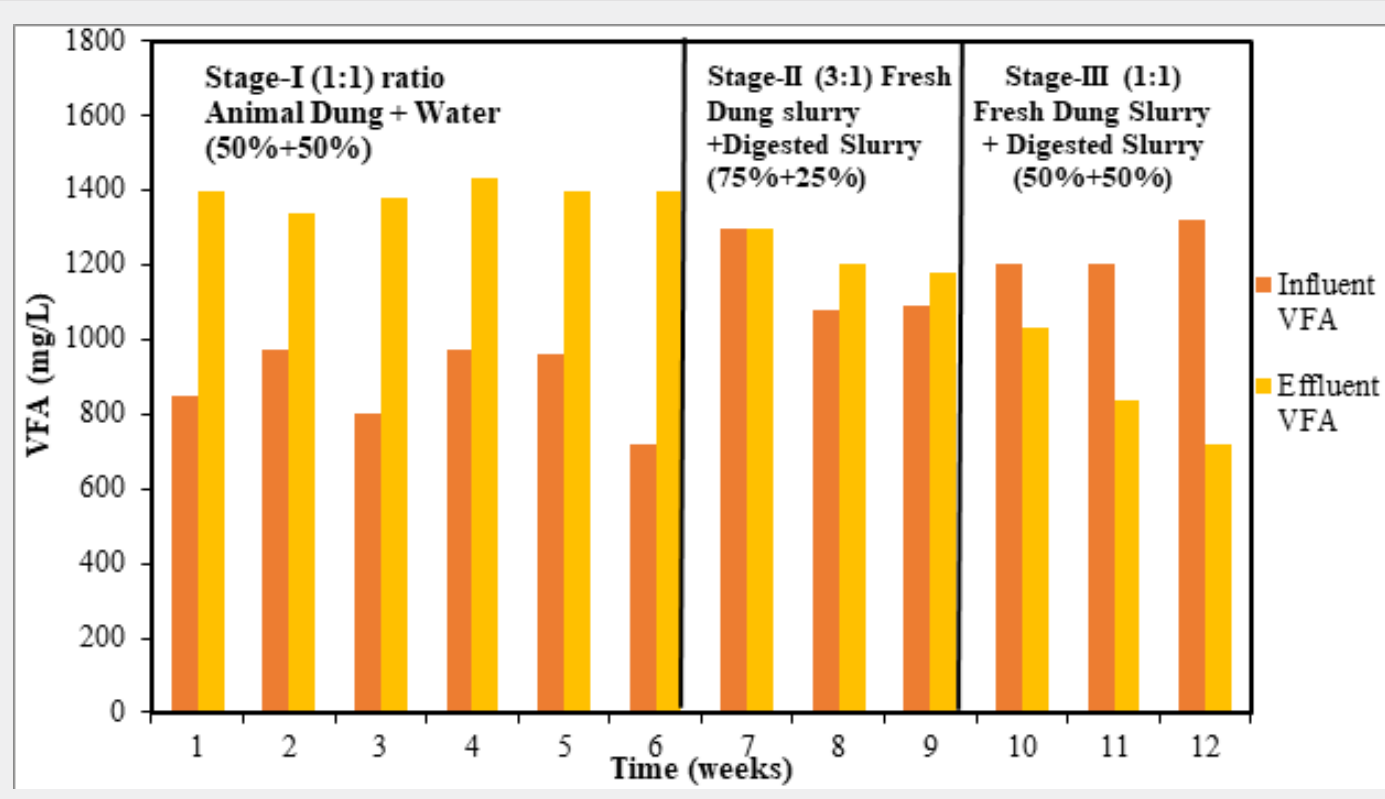

Figure 7: Influent and Effluent VFA.

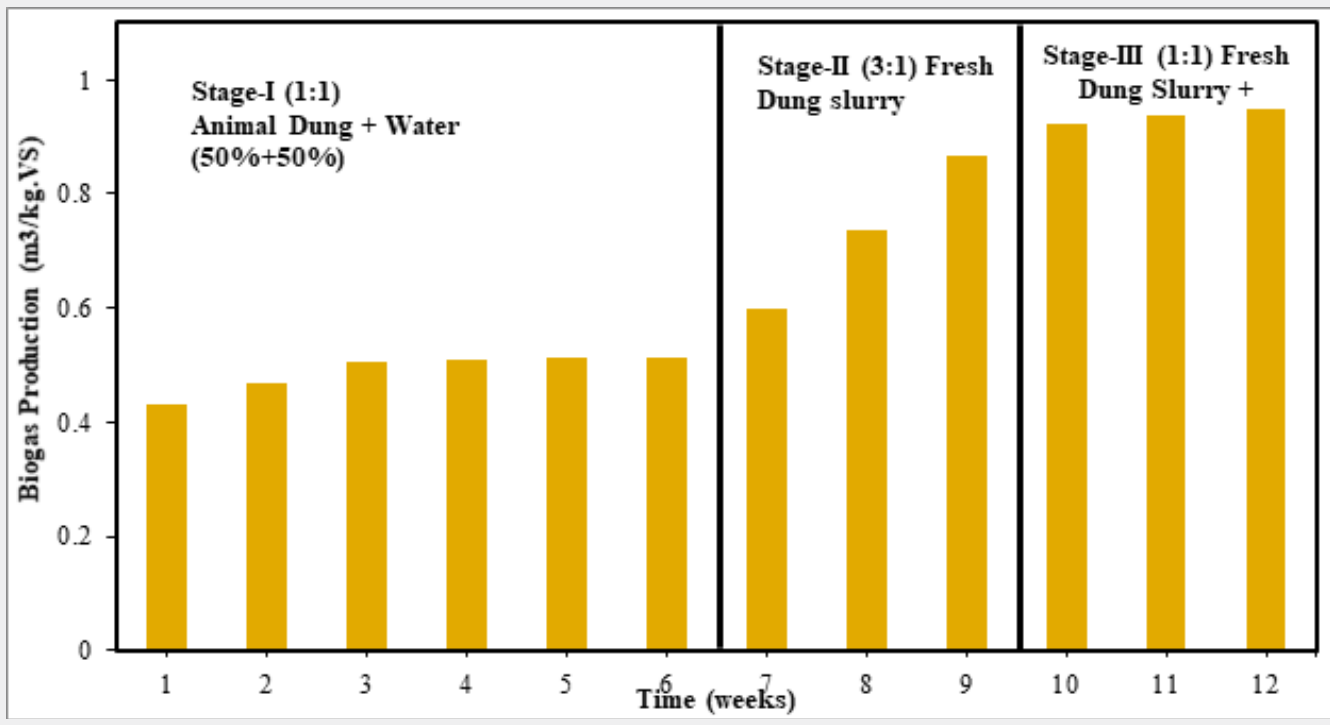

Figure 8: Effect of Slurry Recycling on Biogas Production.

\section{Performance of biogas digester}

The fixed dome biogas plant was operated on various conditions including different ratios and temperature inside the digester. The digester performance was monitored throughout the study and it was assessed by measuring gas production, VS reduction, and $\mathrm{CH}_{4}$ content. In stage-I, the biogas production was achieved to $0.4325 \mathrm{~m}^{3} / \mathrm{kg}$.VS with $\mathrm{CH}_{4}$ content of $64 \%$ and $34 \%$ of $\mathrm{CO}_{2}$; whereas the VS reduction was $23 \%$ when slurry temperature was $27^{\circ} \mathrm{C}$. During stage-II the biogas production was achieved to $0.5386 \mathrm{~m}^{3} / \mathrm{kg}$.VS with $\mathrm{CH}_{4}$ content of $65 \%$ and $35 \%$ of $\mathrm{CO}_{2}$; whereas the VS reduction was $31 \%$ and slurry temperature was $29^{\circ} \mathrm{C}$. Moreover, the highest biogas production and VS reduction was achieved to $0.985 \mathrm{~m}^{3} / \mathrm{kg}$.VS and $39 \%$ respectively. 
In addition maximum $\mathrm{CH}_{4}$ content was $68 \%$ and $\mathrm{CO}_{2}$ content was $31 \%$ during stage-III as shown in (Table 4). The methanogens growth rate was temperature dependent and specific low at low temperature $\left(<20^{\circ} \mathrm{C}\right.$ ) (Rana et al. 2021 and Shamurad et al. 2020). However, in some regions spring is warm and winter cold season the low temperatures $\left(<20^{\circ} \mathrm{C}\right)$ are not suitable for biogas production (Mahmudul et al. 2020). The results shows that the biogas production is also temperature dependent because as slurry temperature increases the biogas production and VS reduction increases. The result suggests that a different and more active consortium of microorganisms were developed or may be dominant in the mesophilic as found in other studies $[27,28]$.

Table 4: Performance of fixed dome biogas plant at various operating Conditions.

\begin{tabular}{|c|c|c|c|c|c|c|c|c|}
\hline Stages & $\begin{array}{l}\text { Duration } \\
\text { (Weeks) }\end{array}$ & Feeding Source & Description & $\mathrm{T}\left({ }^{\circ} \mathrm{C}\right)$ & $\begin{array}{l}\text { Biogas Pro- } \\
\text { duction m }{ }^{3} / \\
\text { kg.VS }\end{array}$ & VS Reduction & $\mathrm{CH}_{4} \%$ & $\mathrm{CO}_{2} \%$ \\
\hline I & 6 & $\begin{array}{l}\text { Animal Dung and } \\
\text { Water }(1: 1)\end{array}$ & $\begin{array}{l}\text { Animal Dung + Water } \\
\qquad(50 \%+50 \%)\end{array}$ & 27 & 0.4325 & 23 & 64 & 34 \\
\hline II & 3 & $\begin{array}{l}\text { Fresh Dung Slurry and } \\
\text { Digested Slurry (3:1) }\end{array}$ & $\begin{array}{l}\text { Fresh Dung Slurry + Digested } \\
\text { Slurry }(75 \%+25 \%)\end{array}$ & 29 & 0.5386 & 31 & 65 & 35 \\
\hline III & 3 & $\begin{array}{l}\text { Fresh Dung Slurry and } \\
\text { Digested Slurry (1:1) }\end{array}$ & $\begin{array}{c}\text { Fresh Dung Slurry + Digested } \\
\text { Slurry }(50 \%+50 \%)\end{array}$ & 32 & 0.9851 & 39 & 68 & 31 \\
\hline
\end{tabular}

\section{Conclusion}

This study was conducted to recycle the digested slurry of fixed dome biogas plant for maximum production of biogas. The biogas plant was operated at various conditions including fresh buffalo dung to water at 1:1 ratio and recycled digested slurry to fresh dung slurry at 3:1 and 1:1 ratio. The biogas production was obtained to $0.4325 \mathrm{~m}^{3} / \mathrm{kg}$.VS at $1: 1$ ratio of dung with water and $0.5386 \mathrm{~m}^{3} / \mathrm{kg}$.VS biogas production was achieved at (3:1) ratio. The maximum biogas production was achieved to $0.98519 \mathrm{~m}^{3} /$ $\mathrm{kg}$.VS with $68 \%$ of $\mathrm{CH}_{4}$ content. It was observed that the recycling of digested slurry back into the digester was suitable for the fixed dome biogas plant for the production of maximum biogas. It was also noted that the highest VS reduction was achieved when slurry was reintroduced into the reactor. The biogas production is lower in cold seasons in Pakistan due to drop in temperature. The recycling of digested slurry with fresh slurry would be beneficent and helping in overcoming the problems of biogas plants for lower biogas production in cold seasons. Additionally, as the experiments was conducted for three months, further study could be carried out by using a heating control unit in winter season to avoid instability in biogas production.

\section{Acknowledgement}

The principal investigator project and team would like to acknowledge the Higher Education Commission, Government of Pakistan for providing funding for this research under HEC NRPU8921 Project titled: "Design, fabrication and optimization of fixed dome biogas plant and digest separator for underprivileged communities living at lower Indus region of Pakistan". The authors would also like to acknowledge to Institute of Environmental Engineering and Management, Mehran University of Engineering \& Technology, Jamshoro, 76062, Sindh, Pakistan, for providing all possible availabilities for this research.

\section{Funding Source}

Higher Education Commission, Government of Pakistan for providing funding for this research under HEC NRPU-8921 Project.

\section{Author Contribution}

Hamza Baloch \& Barkatullah Kandhro: Writing original draft, Conceptualization, Methodology, Formal Analysis, Software's. Azizullah Channa: Conceptualization, Methodology, Formal Analysis, Software's Data calculation. Sheeraz Ahmed Memon: Supervision, Validation, Design, Investigation, Resources, Project administration, Review and editing. Muhammad Yousuf Jat Baloch: Visualization, Methodology, Formal Analysis, Software's. Review and editing, Data calculations. Abdul Aziz Chan: Review and editing. All authors commented on the previous version and approved the final manuscript.

\section{Declaration of Competing Interest}

The authors declare that they have no competing, financial interests or personal relationships that could have appeared to influence the work reported in this paper.

\section{References}

1. Volpe M, JL Goldfarb, LJBT Fiori (2018) Hydrothermal carbonization of Opuntia ficus-indica cladodes: Role of process parameters on hydrochar properties. Bioresour Technol 247: 310-318.

2. Baloch MYJ, SH Mangi (2019) Treatment of synthetic greywater by using banana, orange and sapodilla peels as a low cost activated carbon. J Mater Envir Sciences 10(10): 966-986.

3. Baloch MYJ, Talpur SA, Talpur HA, Iqbal J, Mangi SH, et al. (2020) Effects of Arsenic Toxicity on the Environment and Its Remediation Techniques: A Review. Journal of Water and Environment Technology 18(5): 275-289.

4. Padam BS, Tin SH, Chye FY, Abdullah MI (2014) Banana by-products: an under-utilized renewable food biomass with great potential. J Food Sci Technol 51(12): 3527-3545. 
5. Vu HT, CJ Scarlett, QV Vuong (2018) Phenolic compounds within banana peel and their potential uses: A review. Journal of Functional Foods 40: 238-248.

6. Baloch MYJ, et al, Review Paper Process Design for Biohydrogen Production from Waste Materials and Its Application.

7. Al-Hamamre Z, Siadan M, Hararah M, Rawajfeh K, Alkhasawneh HE, et al. (2017) Wastes and biomass materials as sustainable-renewable energy resources for Jordan. Renewable and Sustainable Energy Reviews 67: 295-314

8. Mirza UK, Ahmad N, Majeed T (2008) An overview of biomass energy utilization in Pakistan. Renewable and Sustainable Energy Reviews 12(7): 1988-1996.

9. Ramachandra T, Kamakshi G, Shruthi BV (2004) Bioresource status in Karnataka. Renewable and Sustainable Energy Reviews 8(1): 1-47.

10. Sarıkoç S (2020) Bioenergy Potential of Turkey's Forest Sources, Biomass Energy Conversion Methods, Products, and Applications. Renewable Energy-Technologies and Applications.

11. Lopes WS, VD Leite, S Prasad (2004) Influence of inoculum on performance of anaerobic reactors for treating municipal solid waste. Bioresource Technology 94(3): 261-266.

12. Chynoweth DP, JM Owens, RJR Legrand (2001) Renewable methane from anaerobic digestion of biomass. Renewable Energy 22(1-3): 1-8.

13. Ishikawa S, et al. (2006) Evaluation of a biogas plant from life cycle assessment (LCA). International Congress Series. Elsevier.

14. Demirbas A, T Ozturk (2005) Anaerobic digestion of agricultural solid residues. International Journal of Green Energy 1(4): 483-494.

15. Alvarez R, G Lidén (2008) The effect of temperature variation on biomethanation at high altitude. Bioresour Technol 99(15): 72787284.

16. de Freitas Melo D, Neves PN, Riberio TB, de Lemos Chernicharo CA, Passos F (2021) The effect of seasonality in biogas production in full-scale UASB reactors treating sewage in long-term assessment. International Journal of Sustainable Energy 40(3): 207-217.

17. Liu M, Y Wei, X Leng (2021) Improving biogas production using additives in anaerobic digestion: A review. Journal of Cleaner Production 297: 126666.
18. Sreekrishnan T, S Kohli, V Rana (2004) Enhancement of biogas production from solid substrates using different techniques--a review. Bioresource Technology 95(1): 1-10.

19. Nie E, He P, Zhang H, Hao L, Shao L, et al. (2021) How does temperature regulate anaerobic digestion? Renewable and Sustainable Energy Reviews 150: 111453.

20. Zamri M, Hasmady S, Akhiar A, Ideris F, Shamsuddin AH, et al. (2021) A comprehensive review on anaerobic digestion of organic fraction of municipal solid waste. Renewable and Sustainable Energy Reviews 137: 110637

21. Fadzil F, Fadzil F, Noraman AF, Seswoya R (2021) Pilot-scale Anaerobic Digestion of Food Waste: Evaluation on the Stability, Methane Production, and Kinetic Analysis.

22. Jukuri S, et al. (2021) Biochemical process evaluation of an anaerobic digester: a case study on long sustain commercial biogas plant. pp. $1-10$.

23. Liu CF, Yuan XZ, Zeng GM, Li WW, Li J (2008) Prediction of methane yield at optimum $\mathrm{pH}$ for anaerobic digestion of organic fraction of municipal solid waste. 99(4): 882-888.

24. Yang L, Huang Y, Zhao M, Huang Z, Miao H, et al. (2015) Enhancing biogas generation performance from food wastes by high-solids thermophilic anaerobic digestion: Effect of $\mathrm{pH}$ adjustment. International Biodeterioration \& Biodegradation 105: 153-159.

25. Quintana Najera J, Blacker AJ, Fletcher LA, Ross AB (2022) Influence of augmentation of biochar during anaerobic co-digestion of Chlorella vulgaris and cellulose. Bioresour Technol 343: 126086.

26. Gao M, Yang M, Ma X, Xie D, We C, et al. (2021) Effect of co-digestion of tylosin fermentation dreg and food waste on anaerobic digestion performance. Bioresour Technol 325: 124693.

27. Karakashev D, Batstone DJ, Angelidaki I (2005) Influence of environmental conditions on methanogenic compositions in anaerobic biogas reactors. Appl Environ Microbiol 71(1): 331-338.

28. Mladenovska Z, BK Ahring (2000) Growth kinetics of thermophilic Methanosarcina spp. isolated from full-scale biogas plants treating animal manures. FEMS Microbiol Ecol 31(3): 225-229.

\section{Your next submission with Juniper Publishers} will reach you the below assets

- Quality Editorial service

- Swift Peer Review

- Reprints availability

- E-prints Service

- Manuscript Podcast for convenient understanding

- Global attainment for your research

- Manuscript accessibility in different formats

( Pdf, E-pub, Full Text, Audio)

- Unceasing customer service

Track the below URL for one-step submission https://juniperpublishers.com/online-submission.php 